\title{
Posisi Ilmu Bahasa Arab dalam Kajian Islam (Perspektif Filsafat Ilmu)
}

\author{
Tati Nurhayati \\ tatinurhayati01@yahoo.co.id \\ (Fakultas Adab dan Ilmu Budaya UIN Sunan Kalijaga) \\ Misnatun \\ natmurian@gmail.com \\ STIT Aqidah Usymuni Sumenep
}

\begin{abstract}
Science and religion are both tools for searching the truth, even though they cannot be categorized as something similar. Islam as a religion, is certainly one of the tools for humans to seek the truth. In Islamic studies, there are three models of thinking to determine the location of the authority of truth, which later by al-Jabiri is matched with the epistemological model popular in Islamic studies, one of which is the epistemology of bayani. Based on this bayani epistemology that to find a truth in Islamic studies, it must refer to the text. The text which is the main source of truth in Islamic studies is the Qur'an and hadith. Qur'an and hadith are arranged in Arabic. From here it is clear that there is an important role or position in Arabic science in Islamic studies. Based on the study by the author that the position of Arabic language science in Islamic studies is as a tool to find the truth or study the contents contained in the Qur'an and the Sunnah which are sources of truth in Islamic studies and the main sources of Islamic teachings. So that the contents of the Qur'an and the Sunnah can be understood by the followers of Islam (Muslim) appropriately and avoid mistakes in the meaning of its contents.
\end{abstract}

Keywords: Arabic Language Science, Islamic Studies.

\section{Pendahuluan}

Ilmu merupakan salah satu alat bagi manusia untuk mencari kebenaran. Selain ilmu, ada agama yang juga merupakan alat untuk mencari kebenaran. Walaupun tujuan kedua aspek ini utuk mencari kebenaran, namun keduanya tidak dapat dikategorikan sebagai sesuatu yang sama. Secara umum, agama mengedepanan wahyu/ilham dari zat yang dianggap Tuhan, sehingga segala sesuatu yang berasal dari Tuhan, dalam perspektif agama adalah sebuah kebenaran yang tidak dapat ditolak. Sedangkan ilmu adalah seperangkat metode untuk mencari kebenaran yang bersumberkan ra'yu (akal, budi, rasio).

Islam sebagai agama, tentu merupakan salah satu alat bagi manusia dalam mencari kebenaran. Dalam kajian Islam, terdapat tiga model berfikir untuk menentukan letak otoritas kebenaran, yang 
kemudian oleh al-Jabiri dipadankan dengan model epistemologi yang populer dalam studi Islam, dapat digambarkan berikut, yakni linguistik atau tekstual (bayani), demonstratif (burhani), dan gnostic/intuitif ('irfani).

Epistemologi bayani adalah pendekatan dengan cara menganalisis teks. Maka sumber epistemologi bayani adalah teks. Dapat berarti bahwa dalam epistemologi bayani yang menjadi otoritas kebenaran adalah terletak pada teks. Adapun teks yang merupakan sumber pokok kebenaran dalam kajian Islam adalah Alquran dan Sunnah Nabi Muhammad SAW (hadits). Berdasarkan epistemologi bayani ini, maka untuk menemukan suatu kebenaran di dalam kajian Islam, harus merujuk pada teks Alquran dan hadits. Sedangkan Alquran dan hadits disusun dengan menggunakan bahasa Arab, maka jelaslah terdapat peranan atau posisi penting ilmu bahasa dalam kajian Islam, terkhusus adalah Ilmu Bahasa Arab.

Adapun kajian dalam ilmu bahasa Arab diantaranya yaitu fonologi ('ilm al-ashwat), morfologi (sharaf), sintaksis (nahwu), dan semantik (dalalah). Namun dalam makalah ini, hanya akan berfokus pada posisi ilmu nahwu dalam mengkaji Alquran dan hadits yang merupakan sumber kebenaran dalam kajian Islam.

Berdasarkan pemaparan di atas, maka dalam artikel ini akan dipaparkan pembahasan mengenai posisi ilmu bahasa Arab dalam kajian Islam yang difokuskan pada posisi ilmu nahwu dalam mengkaji Alquran dan hadits.

\section{A. Hubungan Ilmu dengan Agama}

Pengertian agama dari segi bahasa diungkapkan oleh Harun Nasution bahwa dalam masyarakat Indonesia selain dari kata agama, dikenal pula kata din dari bahasa Arab dan kata religi dalam bahasa Eropa. Menurutnya, agama berasal dari bahasa Sanskrit, yang tersusun dari dua kata, a = tidak, dan gama = pergi, jadi agama artinya tidak pergi, tetap di tempat, diwarisi secara turun temurun. Hal tersebut menunjukkan salah satu sifat agama, yaitu diwarisi secara turun temurun dari satu generasi ke generasi lainnya. ${ }^{1}$ Adapun menurut istilah, banyak definisi tentang agama yang dikemukakan para ahli, disimpulkan oleh Nasution, bahwa agama adalah pengakuan terhadap adanya hubungan manusia dengan kekuatan ghaib yang harus dipatuhi, pengakuan terhadap kekuatan gaib yang menguasai manusia, mengikatkan diri pada suatu bentuk hidup yang mengandung pengakuan pada suatu sumber yang berada di luar diri manusia yang mempengaruhi

\footnotetext{
${ }^{1}$ Abudin Nata, Metodologi Studi Islam, (Jakarta: Rajawali Press, 2010), hlm. 15.
} 
perbuatan-perbuatan manusia, kepercayaan pada suatu kekuatan gaib yang menimbulkan cara hidup trtentu, suatu sistem tingkah laku yang berasal dari kekuatan gaib, pengakuan terhadap kewajibankwajiban yang diyakini bersumber pada kekuatan gaib, pemujaan terhadao kekuatan gaib yang timbulo dari perasaan lemah dan perasaan takut terhadap kekuatan misterius yang terdapat dalam alam sekitar manusia, dan ajaran yang diwahyukan Tuhan kepada manusia melalui seorang Rasul. ${ }^{2}$

Adapun pengertian ilmu secara bahasa, berasal dari bahasa arab: 'alima, ya 'lamu, 'ilman yang berarti mengetahui, mengerti, dan memahaami benar-benar. ${ }^{3} \mathrm{Ilmu}$ adalah kumpulan pengetahuan yang disusun secara sistematis, konsisten dan kebenarannya telah teruji secara empiris. Adapun menurut Jujun S. Suriasumantri, pengertian ilmu adalah salah satu dari buah pemikiran manusia dalam menjawab pertanyaan-pertanyaan. ${ }^{4}$

Agama dan Ilmu merupakan alat untuk manusia dalam mencari kebenaran. Walaupun tujuan kedua aspek ini utuk mencari kebenaran, namun keduanya tidak dapat dikategorikan sebagai sesuatu yang sama. Secara umum, agama mengedepankan wahyu/ilham dari zat yang dianggap Tuhan, sehingga segala sesuatu yang berasal dari Tuhan, dalam perspektif agama adalah sebuah kebenaran yang tidak dapat ditolak.Sedangkan ilmu adalah seperangkat metode untuk mencari kebenaran yang bersumberkan ra'yu (akal, budi, rasio).Sebagian ahli agama menjadikan ilmu sebagai alat untuk mempertajam pemahaman terhadap agama, sehingga kebenaran terhadap agama semakin kuat. ${ }^{5}$

\section{B. Peletakan Posisi Ilmu Bahasa Arab dalam Kajian Islam}

Secara bahasa, posisi dapat berarti letak, kedudukan (orang, barang). Adapun Islam secara bahasa berasal dari bahasa Arab, yaitu salima yang berarti selamat sentosa. Dari asal kata tersebut dibentuk kata aslama yang artinya memelihara dalam keadaan selamat sentosa dan berarti pula menyerahkan diri, tunduk, patuh, dan taat. Adapun Islam secara istilah adalah nama bagi suatu agama yang berasal dari Allah. ${ }^{6}$

Untuk mengetahui posisi ilmu bahasa Arab dalam kajian Islam, maka perlu terlebih dahulu mengkaji model berpikir dalam kajian islam (epistemologi kajian Islam), terkhusus epistemologi

\footnotetext{
${ }^{2}$ Abudin Nata, Metodologi Studi Islam..., hlm. 15.

3 Abdul Wahid, Korelasi Agama, Filsafat dan Ilmu, Jurnal Substantia, Vol. 14, No.2, 2012, Abudin Nata, Metodologi Studi Islam, (Jakarta: Rajawali Press, 2010), hlm. 9.hlm. 225.

${ }^{4}$ Mohammad Adib, Filsafat Ilmu, (Yogyakarta: Pustaka Pelajar, 2010), hlm. 50.

${ }^{5}$ Abdul Wahid, Korelasi Agama, Filsafat dan Ilmu..., hlm. 224.

${ }^{6}$ Abudin Nata, Metodologi Studi Islam..., hlm. 62-65.
} 
bayani. Berikut penjelasan mengenai bagaimana epistemologi bayani melatarbelakangi peletakan posisi ilmu bahasa Arab dalam kajian islam :

\section{Model Berpikir Kajian Islam}

Model berpikir dalam kajian islam disebut oleh al-Jabiri dengan model epistemologi dalam kajian Islam. Epistemologi merupakan pembahasan mengenai bagaimana kita mendapatkan pengetahuan: apakah sumber-sumber pengetahuan, apakah hakikat, jangkauan dan ruang lingkup pengetahuan, apakah manusia dimungkinkan untuk mendapatkan pengetahuan, dan sampai tahap mana pengetahuan yang mungkin untuk ditangkap manusia. ${ }^{7}$

Dapat disebut bahwa ada tiga model berpikir yang berkembang dalam sejarah (khazanah pemikiran umat manusia), dan sekaligus menjadi tolak ukur kebenaran, yaitu empirisme, rasionalisme, dan intuitif. Sedangkan dalam perspektif Islam, ketiga model berpikir tersebut dipadankan dengan epistemologi yang populer dalam kajian Islam oleh al-Jabiri, yakni :

Pertama, model berpikir linguistik/tekstual (epistemologi bayani), yaitu pendekatan dengan cara menganalisis teks. Maka sumber epistemologi bayani adalah teks.Dapat berarti bahwa dalam epistemologi bayani, yang menjadi otoritas kebenaran adalah terletak pada teks. Adapun teks yang merupakan sumber pokok dalam kajian Islam adalah teks nash (Alquran dan Sunnah Nabi Muhammad SAW./hadits), dan teks non nash berupa karya para ulama.

Adapun objek kajian yang umum dengan pendekatan bayani adalah gramatika dan sastra (nahwu dan balaghah), hukum dan teori hukum (fiqih dan usul fiqih), filologi, teologi, dan dalam beberapa kasus di bidang ilmu-ilmu Alquran dan hadits. Adapun corak berpikir yang diterapkan dalam ilmu ini cenderung deduktif, yakni mencari (apa) isi dari teks (analisis content). ${ }^{8}$

Kedua, metode berpikir demonstratif (epistemologi burhani) adalah bahwa untuk mengukur benar atau tidaknya sesuatu adalah dengan berdasarkan komponen kemampuan alamiah manusia berupa pengalaman dan akal tanpa dasar teks wahyu suci, yang memunculkan eripatik.Maka sumber pengetahuan dengan nalar burhani adalah realitas dan empiris; alam, sosial, dan humanities.Artinya, ilmu diperoleh sebagai hasil penelitian, hasil percobaan, hasil eksperimen, baik di laboratorium maupun di alam nyata, baik yang bersifat sosial maupun

\footnotetext{
${ }^{7}$ Jujun S. Suriasumantri, Filsafat ilmu Sebuah Pengantar Populer, (Jakarta: Sinar harapan, 1982), hlm.

${ }^{8}$ Khoiruddin Nasution, Pengantar Studi Islam, (Yogyakarta: ACAdeMIA + TAZZAFA, 2012), hlm. 41-42.
} 
alam.Corak berpikir yang digunakan adalah induktif, yakni generalisasi dari hasil-hasil penelitian empiris. $^{9}$

Ketiga, metode berpikir Gnostik/Intuitif (Epistemologi 'Irfani), adalah pendekatan yang bersumer pada intuisi (kasyf/ilham). ${ }^{10}$

Dari ketiga epistemologi tersebut, yang menjadi kajian pokok adalah epistemologi bayani.Dalam epistemologi ini yang menjadi sumber kebenaran dalam kajian islam adalah teks, baik Alquran, hadits, maupun karya para ulama. Hal ini kemudian memunculkan adanya kesepakatan di kalangan para ulama bahwa sumber pokok kajian Islam adalah Alquran dan sunnah nabi Muhammad SAW. (hadits).

Alquran -secara bahasa maupun secara istilah- memiliki pengertian yang beragam. Al-Farra mengatakan bahwa lafal Alquran berasal dari kata qarain jamak dari qarinah yang berarti kaitan; karena dilihat dai segi makna dan kandungannya, ayat-ayat Alquran itu satu sama lain saling berkaitan. Sedangakan menurut istilah, Alquran adalah kitab suci yang isinya mengandung firman allah, diturunkan secara bertahap melalui malaikat Jibril, pembawanya Nabi Muhammad Saw., susunannya diawali dengan surat Al-Fatihah dan diakhiri dengan surat An-Nas, bagi yang membacanya bernilai ibadah, fungsinya antara lain menjadi hujjah atau bukti yang kuat atas kerasulan Nabi Muhammad saw., keberadaannya hingga kini masih tetap terpelihara dengan baik, dan pemasyarakatannya dilakukan secara berantai dari satu generasi ke generasi lain dengan tulisan maupun lisan. ${ }^{11}$

Al-Sunnah menurut bahasa artinya jalan hidup yang dibiasakan, terkadang jalan tersebut ada yag baik dan ada pula yang buruk. Pengertian al-Sunnah ini sejalan dengan makna hadits Nabi yang diriwayatkan oleh Imam Muslim, yang artinya: "barang siapa yang membuat Sunnah (kebiasaan) yang terpuji, maka pahala bagi yang membuat sunnah itu dan pahala bagi yang mengerjakannya; dan barangsiapa yang membuat sunnah yang buruk, maka dosa bagi yang membuat sunnah yang buruk itu daan bagi orang yang mengerjakannya. Kebanyakan para ulama ahli hadits mengartikan Al-Sunnah, al-Hadits, Al-Khabar, dan Al-Atsar dengan pengertian yang sama, yaitu segala sesuatu yang disandarkan kepada Nabi Muhammad Saw. baik berupa ucapan, perbuatan maupun ketetetapan. ${ }^{12}$

\footnotetext{
${ }^{9}$ Khoiruddin Nasution, Pengantar Studi Islam..., hlm. 43.

${ }^{10}$ Khoiruddin Nasution, Pengantar Studi Islam..., hlm. 43.

${ }^{11}$ Abudin Nata, Metodologi Studi Islam..., hlm. 67-69.

12 Abudin Nata, Metodologi Studi Islam..., hlm. 72-73.
} 


\section{Posisi Ilmu Bahasa Arab dalam Kajian Islam}

Seperti yang telah dijelaskan di atas, bahwa dari ketiga epistemologi tersebut, yang menjadi kajian pokok dalam mengidentifikasi posisi ilmu bahasa Arab dalam kajian islam adalah epistemologi bayani.

Maka setelah memahami model berpikir bayani dalam kajian Islam tersebut dapat disimpulkan bahwa posisi ilmu bahasa Arab dalam kajian Islam adalah sebagai alat untuk mencari kebenaran atau menjelaskan isi yang terdapat di dalam Alquran dan Al-Sunnah yang merupakan sumber kebenaran dalam kajian Islam. Kesimpulan tersebut berdasarkan latar belakang berikut :

a. Dalam epistemologi bayani, yang menjadi sumber kebenaran dalam kajian islam adalah teks, baik Alquran, hadits, maupun karya para ulama.

b. Adapun teks adalah merupakan serangkaian bahasa. Maka untuk mempelajari teks diperlukan adanya ilmu bahasa, sebagai alat untuk mencari kebenaran di dalam teks, atau untuk menjelaskan isi dari teks tersebut. Sehingga jelas bahwa diperlukan ilmu bahasa untuk mencari kebenaran dan menjelaskan isi yang terdapat di dalam Alquran dan Al-Sunnah yang merupakan sumber kebenaran dalam kajian Islam.

c. Teks Alquran dan al-Sunnah disusun dengan menggunakan bahasa Arab, sehingga jelas bahwa ilmu bahasa Arab memiliki posisi penting dalam kajian islam, yaitu sebagai alat untuk mencari kebenaran atau mengkaji isi yang terdapat di dalam Alquran dan Al-Sunnah yang merupakan sumber kebenaran dalam kajian Islam dan sumber pokok ajaran Islam. Sehingga isi kandungan Alquran dan Al-Sunnah dapat dipahami oleh para pemeluk agama Islam (muslim) secara tepat dan terhindar dari kesalahan dalam pemaknaan isinya.

\section{Posisi Ilmu Nahwu dalam Mengkaji Alquran dan Hadits}

Ilmu nahwu merupakan salah satu ilmu bahasa Arab. Di dalamnya dibicarakan bentuk-bentuk susunan kalimat serta penentuan harakat akhir setiap kata dalam kalimat tersebut. Dengan mempelajari ilmu ini seseorang akan lebih mudah dalam memahami kalimat bahasa Arab karena ia dapat mengetahui kedudukan setiap kata dalam kalimat tersebut, baik sebagai mubtada', khabar, fa'il, maf'ul atau lainnya. ${ }^{13}$

\footnotetext{
${ }^{13}$ Abdullah Habib, Ilmu Nahwu: Al-nahwu Al-Muyassar, (Yogyakarta: CV. Aswaja Pressindo, 2014), hlm.3.
} 
Sebagai salah satu dari ilmu bahasa Arab, maka ilmu nahwu memiliki posisi penting dalam kajian Islam, yaitu sebagai alat untuk mencari kebenaran atau mengkaji isi dari Alquran dan AlSunnah sebagai sumber kebenaran dan sumber ajaran dalam kajian Islam.

Contoh aplikasi dari peran ilmu nahwu di dalam mengkaji Alquran :

$$
\text { إنَّمَا يَخْشَى اللَّهَ مِنْ عِبَادِه الْعْلَمَاءُ }
$$

Penjelasan I'rab:

$$
\text { - إنَََّا: إن حرف التوكيد مبني على فتح, ما حرف النفي مبني على سكون }
$$

Dalam bait alfiyah karangan Ibnu Malik diterangkan bahwa bersambungnya huruf maa dengan Inna, membatalkan terhadap pengamalan Inna. Terkadang ada juga pengamalannya yang ditetapkan, namun sangat jarang.

Hasan Al-Jaizy dalam tulisannya mengenai bahasa, bahasa Arab dan ushul fiqih disebutkan bahwa lafadz Innamaa dimaksudkan sebagai hashr atau pembatasan sehingga maknanya adalah 'hanyalah'.

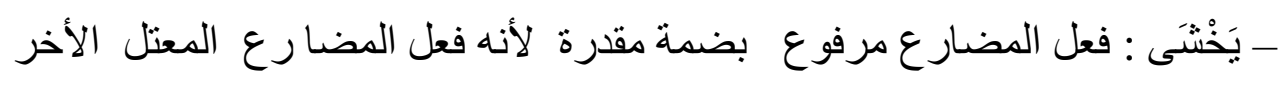

Menunjukkan kata kerja ( $f$ ' $i l)$, yang artinya 'dia takut'.

$$
\text { - اللَّهَ : إسم عالم منصوب بالقتح لأنه الإسم المفرد وهو مفعول به 'ل }
$$

Merupakan kata benda (isim) yang menunjukkan sebuah nama, kedudukannya sebagai maf'ul (objek), berarti yang terkena pekerjaan atau yang ditakuti.

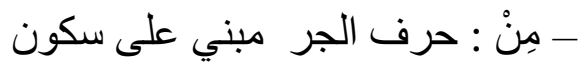

Huruf yang men-jar-kan kata setelahnya, bermakna 'dari'.

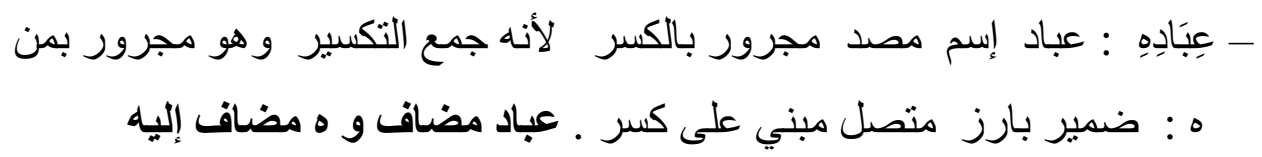

Isim yang di-jar-kan oleh min, yang bermakna banyak ' hamba-hamba-Nya'.

$$
\text { - الْعُلَمَاءُ: إسم مصدر مرفوع بالضمة لأنه جمع تكسير وهوفاعل }
$$

Merupakan kata benda (isim), yang berkedudukan sebagai fa'il (pelaku pekerjaan), dalam arti orang yang takut.

Maka berdasarkan penjelasan I'rob di atas dapat disimpulkan isi dari ayat tersebut, yaitu :

"Sesungguhnya yang takut kepada Allah dari kalangan hamba-hamba-Nya adalah para ulama." 
Kemudian jika lafadz Allaha dibaca Allahu dan 'Ulama'u dibaca 'Ulama'a, maka artinya berubah menjadi:

"Sesungguhnya yang takut kepada para ulama dari kalangan para hamba adalah Allah."

Maka bacaan yang kedua ini adalah bacaan yang batil. Sehingga jelas bahwa posisi ilmu nahwu sangat penting dalam mengkaji isi dari teks Alquran, sehingga memperoleh pemahaman terhadap isi Alquran secara tepat.

Contoh aplikasi dari peran ilmu nahwu di dalam mengkaji hadits :

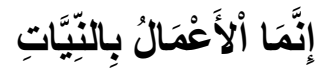

Penjelasan I'rob :

$$
\text { - إِنَّمَا: إن حرف التوكيد مبني على فتح, ما حرف النفي مبني على سكون }
$$

Dalam bait alfiyah karangan Ibnu Malik diterangkan bahwa bersambungnya huruf maa dengan Inna, membatalkan terhadap pengamalan Inna. Terkadang ada juga pengamalannya yang ditetapkan, namun sangat jarang.

Hasan Al-jaizy dalam tulisannya mengenai bahasa, bahasa Arab dan ushul fiqih disebutkan bahwa lafadz Innamaa dimaksudkan sebagai hashr atau pembatasan sehingga maknanya adalah 'hanyalah'.

$$
\text { ـالأعمال : إسم مصدر مرفوع بالضمة لأنه التكسيرجمع وهو مبتدأ }
$$

Merupakan kata benda (isim), yang berkedudukan sebagai mubtada.

$$
\text { - ب : كسر على مبني الجر حرف }
$$

Huruf $b a$ (dibaca $b i$ ) merupakan huruf yang men-jar-kan kata setelahnya. Huruf $b a$ ini memiliki berbagai makna, salah satunya adalah sababiyah. Sehingga maknanya di sini adalah berupa sebab 'bergantung'.

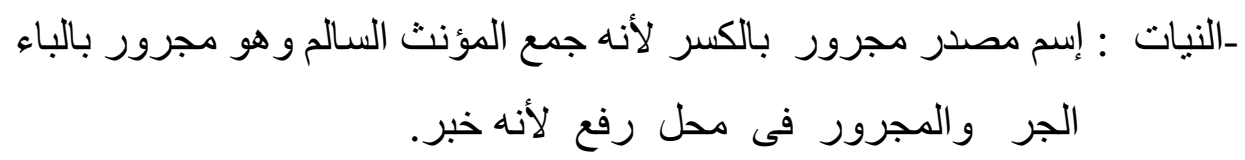

Merupakan kata benda (isim) yang di-jar-kan oleh huruf jar ba. Sehingga maknanya menjadi 'bergantunng pada niat'.Kedudukannya sebagai khobar.

Maka dari penjelasan I'rob di atas, dapat ditarik makna dari hadits tersebut sebagai berikut : "Sesungguhnya amal itu bergantung pada niat."

Hadits ini menjelaskan bahwa penentu baik buruknya amal itu adalah bergantung pada niatnya. Maka dari hasil pengkajian terhadap hadits di atas dapat dilihat bagaimana peran ilmu 
bahasa Arab, khususnya ilmu nahwu, dalam mengkaji makna hadits secara tepat. Sehingga pesan dari hadits tersebut dapat diterima dan dipahami secara tepat dengan adanya alat yaitu seperangkat ilmu bahasa Arab, terkhusus ilmu nahwu.

\section{Penutup}

Dapat disimpulkan bahwa ntuk mengetahui posisi ilmu bahasa Arab dalam kajian islam, maka dapat merujuk pada epistemologi dalam kajian Islam, terkhusus epistemologi bayani, karena dalam epistemologi bayani, sumber kebenaran dalam kajian islam terletak pada teks, baik teks Alquran, hadits, maupun karya para ulama. Teks Alquran dan Al-Sunnah disusun dengan menggunakan bahasa Arab, sehingga jelas bahwa ilmu bahasa Arab memiliki posisi penting dalam kajian islam, yaitu sebagai alat untuk mencari kebenaran ataumengkaji isi yang terdapat di dalam Alquran dan Al-Sunnah yang merupakan sumber kebenaran dalam kajian Islam dan sumber pokok ajaran Islam.

\section{Daftar Pustaka}

Adib, Mohammad. 2010. Filsafat Ilmu. Yogyakarta: Pustaka Pelajar.

Habib, Abdullah. 2014. Ilmu Nahwu: Al-nahwu Al-Muyassar. Yogyakarta: CV. Aswaja Pressindo.

Nasution, Khoiruddin. 2012. Pengantar Studi Islam. Yogyakarta: Academia + TAZZAFA

Nata, Abudin .2010. Metodologi Studi Islam. Jakarta: Rajawali Press.

Suriasumantri, Jujun. 1982. Filsafat ilmu Sebuah Pengantar Populer. Jakarta: Sinar harapan.

Wahid, Abdul. 2012. Korelasi Agama, Filsafat dan Ilmu, Jurnal Substantia, Vol. 14, No.2. 